DIKTUM: Jurnal Syariah dan Hukum

Volume 19 Nomor 1 Juli 2021 hlm: 16-31

\title{
KONTRIBUSI KONSEP TAKWIL ULAMA USHULIYYUN DALAM PEWARISAN BEDA AGAMA
}

\author{
Siti Zuhrotun Ni'mah \\ UIN Maulana Malik Ibrahim Malang \\ Email: zuhrotunnimah95@gmail.com \\ Tutik Hamidah \\ UIN Maulana Malik Ibrahim Malang \\ Email: hamidah.ansori@gmail.com
}

\begin{abstract}
This paper discusses the contribution of the conception of takwil (interpretation) of the Ushuliyyun (theologians) in the concept of inheritance of various religions. The theologians derived the takwil method in the Istibath Ahkam as one of the methodologies of Islamic law. Takwil is a transfer from the foreign meaning to the concealed meaning based on the relevant arguments. This study applies library research as an approach by conducting studies on numerous legal materials considering the concept of takwil in inheritance of various religions. This study contributes comprehensive interpretation view concerning the dubs and educates that must be recognized so that the takwil carried out turns into accepted interpretation. As for takwil which bears no evidence and particularly due to the lust, this interpretation view could not be applied. The purpose of this interpretation approach that dealing with troubles in community concerning Islamic rule could be observed on the takwil application for inheritance in the different religions that are described so as to present the contemporary idea that the inheritance prohibition for different religions is particularly for the harby infidels. A Muslim also can be the heir of the non-Muslim infidels.
\end{abstract}

Keywords: Takwil, Ushuliyyun, Inheritance.

\begin{abstract}
Abstrak
Artikel ini membahas mengenai kontribusi dari konsep takwil para Ushuliyyun dalam kewarisan beda agama. Para Ushuliyyun mewariskan metode takwil dalam Istibath Ahkam sebagai salah satu metodologi hukum Islam. Takwil merupakan pengalihan dari makna dhahir pada makna yang tersembunyi berdasarkan dalil yang dapat dijangkau. Penelitian ini menggunakan kajian kepustakaan (library research) sebagai pendekatan dengan melakukan kajian pada berbagai bahan hukum mengenai konsep takwil dan interpretasinya dalam kewarisan beda agama. Kajian ini menghasilkan konsep takwil secara menyeluruh mengenai ketentuan dan syarat yang harus diketahui agar takwil yang dilakukan menjadi takwil yang maqbul. Adapun takwil yang tidak memiliki dalil dan hanya karena nafsu maka takwil ini tidak bisa diterima. Relevansi konsep takwil dengan penyelesaian permasalahan dalam masyarakat mengenai hukum Islam dapat diketahui salah satunya pada pengaplikasian takwil terhadap konsep pewarisan beda agama yang ditakwilkan sehingga menghasilkan makna bahwa larangan kewarisan beda agama itu hanya diperuntukkan bagi kafir harby. Serta seorang muslim juga tetap bisa menjadi ahli waris dari orang kafir
\end{abstract}

Kata Kunci: Takwil, Ushuliyyun, Kewarisan. 
Siti Zuhrotun Ni' mah \& Tutik Hamdani:

Kontribusi Konsep Takwil Ulama...

\section{Pendahuluan}

Dalam agama Islam memahami kehendak yang dimaksud oleh Syari' ada beberapa metode yang bisa digunakan. Metode ini ditempuh oleh seseorang yang bernama Mujtahid guna menemukan pemahaman yang terdapat pada Al-Qur'an dan hadis. Karena Al-Qur'an maupun hadis terkadang tidak hanya memiliki makna eksplisit namun juga emplisit, maka untuk memahami dari makna tersiratnya perlu ada metode khusus yang digunakan. Dalam hal ini takwil mampu menjadi metode yang dipakai untuk menemukan makna eksoteric atau batin dalam ungkapan suatu teks.

Meskipun terdapat ikhtilaf namun dalam prinsipnya, para Ushuliyyun sepakat bahwa takwil dapat digunakan jika memenuhi ketentuan yang ada. Takwil yang disepakati ini juga bisa disebut dengan takwil maqbul. Dalam melakukan takwil seperti yang dimaksud dalam kajian yang telah dilakukan oleh Syahrial Dedi yang menghasilkan konsep bahwa yang disebut dengan takwil ialah tidak meninggalkan makna dhahirnya namun dengan petunjuk yang sederhana mampu memberikan pemahaman sesuai dengan yang dimaksud dalam teks. ${ }^{1}$ Hal yang sama juga diungkapkan oleh Ibnu Hajib bahwa takwil adalah membawa lafadz kepada sesuatu makna yang tidak dilihatkan secara dhahir. Hal ini dilakukan karena adanya kemungkinan beberapa makna dalam lafadz sehingga diambil makna tersembunyinya. ${ }^{2}$ Jadi jika takwil dilakukan hanya dengan menuruti hawa nafsu atau persyaratan yang ada tidak terpenuhi maka takwil tersebut menjadi takwil yang ghairu maqbul.

Penerapan takwil dapat diketahui salah satunya terdapat dalam firman Allah swt. pada Q.S Al-Baqarah ayat 228. Ayat ini menjelaskan mengenai perempuan yang ditalak oleh suaminya harus melakaukan iddah atau masa tunggu yang dilakukan selama tiga kali masa haid atau suci. Ayat ini berlaku umum baik itu untuk seorang istri yang telah digauli oleh suaminya maupun belum, yang dalam keadaan haid, hamil maupun telah menopause. Lalu ayat ini ditakhsis menggunakan Q.S Al-Ahzab ayat 49 yang menjelaskan bahwa seorang perempuan yang belum digauli oleh suaminya maka tidak memiliki masa iddah dengan lafadz ayat sebagai berikut:

${ }^{1}$ Syahrizal Dedi, “Konsep Ta’ wil Ushuliyyin Dan Relevansinya Dengan Pembaharuan Hukum Islam," Jurnal Ilmiah Syariah 17, no. 01 (2018): 1-18.

${ }^{2}$ Abi Bakr Bin Ali, Bayan Al-Mukhtashar Syarh Mukhtashar Al- Muntaha Al-Ibn Al-Hajib Fi Ushul Al- Figh (Jami'iyah Um al Quro', n.d.).

DIKTUM: Jurnal Syariah dan Hukum Volume 19 Nomor 1 Juli 2021 
Siti Zuhrotun Ni' mah \& Tutik Hamdani:

Kontribusi Konsep Takwil Ulama...

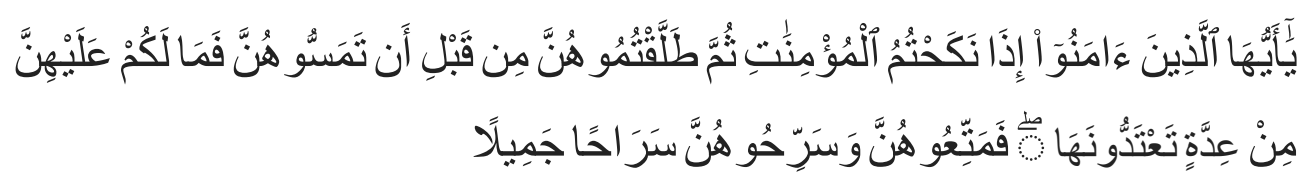

Terjemahnya: "Hai orang-orang yang beriman, apabila kamu menikahi perempuan perempuan yang beriman, kemudian kamu ceraikan mereka sebelum kamu mencampurinya maka sekali-sekali tidak wajib atas mereka iddah bagimu yang kamu minta menyempurnakannya. Maka berilah mereka mut'ah dan lepaskanlah mereka itu dengan cara yang sebaik-baiknya." ${ }^{3}$

Takwil yang dilakukan pada ayat ini tergolongkan sebagai takwil takhshish alumum. Yaitu takwil yang dilakukan dengan mengkhususkan makna lafadz yang masih bersifat umum.

Mengenai sistem kewarisan yang menjadi penyebab seseorang bisa mendapatkan harta warisan yaitu yang pertama merupakan nasab atau kekerabatan. Orang yang satu nasab lebih berhak mendapatkan kewarisan satu sama lain. Kedua pernikahan, adanya ikatan pernikahan juga bisa mengakibatkan seseorang bisa mendapatkan waris, seperti seorang istri bisa mendapatkan hak waris dari suaminya dan sebaliknya. Dan ketiga wala' atau memerdekakan hamba sahaya, apabila ada seseorang yang memerdekakan hamba sahaya dan hamba sahaya tersebut meninggal lalu tidak ada ahli waris sama sekali, maka warisannya bisa diberikan ke orang yang memerdekakannya. ${ }^{4}$ Sedangkan kaitannya terhadap kewarisan beda agama, Terutama di Indonesia yang memiliki masyarakat heterogen dalam beragama, fenomena melakukan pindah agama menjadi hal yang biasa dilakukan saat ini. Selain itu, kemajemukan agama dalam satu keluarga juga banyak ditemui. Maka hal tersebut menimbulkan permasalah saat dibahas mengenai kewarisannya karena ada ahli waris atau orang yang mewariskan hartanya berbeda dalam agama. Sedangkan Islam mengatur bahwa ada larangan untuk saling mewarisi antara seseorang yang beragama Islam dengan orang kafir.

Pada penelitian terdahulu yang dilakukan oleh Chamim Tohari mengenai kontruksi dari kewarisan beda agama dalam tinjauan Ushul al Khamsah menggambarkan mengenai perbedaan hukum saat seorang muslim mewarisi harta dari orang kafir. Ada satu kelompok yang berpedoman pada teks hadis dan tetap melarangnya,serta ada kelompok lain yang tetap memperbolehkan dengan dalil

${ }^{3}$ Al-Qur'an, 33: 49.

${ }^{4}$ Abu Hafzah, Ensiklopedi Fiqih Islam (Ponorogo: Pustaka al-Bayyinah, 2014).961.

DIKTUM: Jurnal Syariah dan Hukum Volume 19 Nomor 1 Juli 2021 
Siti Zuhrotun Ni' mah \& Tutik Hamdani:

Kontribusi Konsep Takwil Ulama...

kemaslahatan. ${ }^{5}$ Selain itu, dalam kajian yang membahas mengenai revitalisasi maqasid syariah pada kewarisan beda agama yang dtulis oleh Wahid Ahtar menghasilkan penemuan bahwa perlu diperhatikan pembacaan teks kemudian diukur dengan nilai-nilai universal syariat demi mewujudkan hukum Islam yang berdampak maslahat riil sehingga kewarisan beda agama dari orang kafir terhadap seorang muslim bisa tetap diperbolehkan. ${ }^{6}$

Oleh karena itu, penelitian ini bertujuan menjadikan takwil sebagai metode dalam memahami dalil agar menghasilkan produk hukum mengenai proses takwil terhadap dalil larangan kewarisan dalam beda agama.

\section{Metode}

Kajian ini dirancang dengan menggunakan metode penelitian kualitiatif. Jenis penelitian yang digunakan adalah penelitian kepustakaan atau library research. Pendekatan yang digunakan ialah normatif atau doktrinal, yang mana pada penelitian ini dilakukan telaah mengenai intrepetasi terhadap konsep takwil para Ushuliyyun. Sumber data primer diperoleh dari kitab - kitab Ushul Figh dalam kalangan Ushuliyyun serta data sekundernya merupakan kitab-kitab penunjang seperti beberapa kitab tafsir dan syarah hadis serta beberapa artikel dan jurnal ilmiah.

Data yang terkumpul kemudian diklasifikasikan dan dianalisis terkait dengan kontribusi konsep takwil para Ushuliyyun dalam kewarisan beda agama. Dalam hal ini adalah pembahasan mengenai konsep takwil dan juga interpretasinya pada sistem kewarisan beda agama.

\section{Hasil dan Pembahasan}

\section{Konsep Takwil}

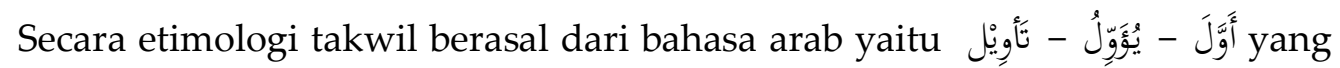
memiliki arti kembali,yakni kembali ke makna yang sebenarnya. Sedangkan dari isi zaman dan maknanya berarti tempat kembali.7 Secara istilah takwil memiliki dua

${ }^{5}$ Chamim Tohari, "Rekonstruksi Hukum Kewarisan Beda Agama Ditinjau Dari Al-Ushul Al Khamsah," Mazahib: Jurnal Pemikiran Hukum Islam 16, no. 1 (2017): 1-4, https://doi.org/: http://dx.doi.org/10.21093/mj.v16i1.625.

6 Wahid Ahtar Baihaqi, "Revitalisasi Maqasid Al-Shariah: Pembacaan Ulang Konsep Kewarisan Beda Agama," Muslim Heritage 1, no. 2 (2017): 107-24.

${ }^{7}$ Moh ridwan Zainuddin, “Tafsir,Ta'wil Dan Terjemah," Al-Allam 1, no. 1 (2020): 1-17.

DIKTUM: Jurnal Syariah dan Hukum

Volume 19 Nomor 1

Juli 2021 
Kontribusi Konsep Takwil Ulama...

pengertian. Pertama yang merupakan persamaan dari tafsir dan yang kedua pengertian yang membedakan dengan tafsir. ${ }^{8}$ Takwil juga dikaji pada beberapa ranah keilmuan seperti tasawuf, ilmu kalam dan ushul fiqh. Masing-masing keilmuan ini memiliki fokus tersendiri dalam melakukan kajian pada takwil. Para ulama tasawuf dan ulama ilmu kalam atau teologi ranah kajiannya pada masalah ushul yang disana menyangkut permasalahan akidah,tentang nash dan sifat- sifat Allah SWT. Sedangkan kajian para ulama ushul fiqh lebih kepada permasalahan furu' yang berkaitan dengan hukum-hukum syariat.

Para ulama ushul fiqih melakukan kajian mendalam terhadap Al-Qur'an maupun hadis guna kepentingan Istinbath Ahkam. Maka para ulama mengungkapkan bahwa dari kajian yang telah dilakukan secara mendalam mengenai takwil, menurut Adib Shalih takwil banyak dilakukan pada berbagai bidang dalam hukum Islam. Misalnya, mengkhususkan lafadz yang umum yang disebut dengan Takhsis al Amm, lalu membatasi lafadz yang muthlaq yang disebut dengan Taqyid al Muthlaq ${ }^{9}$. Serta mengalihkan dari makna hakiki lafadz menjadi makna majazi atau merubah hukum yang semisal dari yang awalnya wajib menjadi sunnah. ${ }^{10}$

Ulama Mutaqadimin atau ulama salaf menurut Ibnu Taimiyah menyamakan antara tafsir dan takwil serta menganggap bersinonim. Mengenai kesamaan ini dapat diketahui pada Jami' al-Bayan fi Ta'wil Ayat al-Qur'an karya pada ungkapan Ibn Jarir ath-Thabari bahwa اختلف أهل التأويل في هذه الأية dan القول في تأويل قوله تعالى كذ و كذ dimaksud takwil dalam kutipan-kutipan tersebut ialah tafsir. ${ }^{11}$

Para ulama Mutaakhirin memiliki pendapat berbeda bahwa takwil berbeda dengan tafsir. Salah satunya Ibnu Hajib yang mengemukakan definisi takwil dengan istilah حمل الظار على المتمل المرجوح yaitu membawa Lafadz menuju makna yang tidak disebutkan secara dhahir. ${ }^{12}$ Imam al Subki memberikan pengertian yang sama mengenai takwil dan memberikan tambahan bahwa dalam mengalihkan makna

\footnotetext{
${ }^{8}$ Dedi, “Konsep Ta' wil Ushuliyyin Dan Relevansinya Dengan Pembaharuan Hukum Islam.” ${ }^{9}$ Satria Effendi, Ushul Fiqih (Jakarta: Kencana, 2009).231.

${ }^{10}$ Wahbah az-Zuhaili, Ushul Al-Figh Al-Islami (Damsyiq: Dar al-Fikr, 1986).314.

${ }^{11}$ Syarial Dedi, “Ushul Al-Fiqh Dan Kontribusinya (Konsep Ta’ wil Dan Relevansinya Dengan Pembaharuan Hukum Islam)," Al Istinbath : Jurnal Hukum Islam 2, no. 2 (2017): 103-6.

${ }_{12}$ Bin Ali, Bayan Al-Mukhtashar Syarh Mukhtashar Al-Muntaha Al-Ibn Al-Hajib Fi Ushul AlFigh.416.
}

DIKTUM: Jurnal Syariah dan Hukum Volume 19 Nomor 1 Juli 2021 
Kontribusi Konsep Takwil Ulama...

tersebut harus dengan adanya dalil yang sesuai. Adapun saat hanya didasarkan pada anggapan belaka maka hal seperti ini tidak bisa disebut dengan takwil. ${ }^{13}$

Menurut Imam Syafii menjelaskan mengenai takwil dengan ungkapan yaitu:

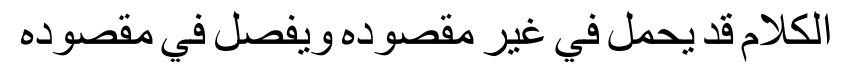

Artinya: "Pada suatu kalimat atau perkataan terkadang memiliki maksud lain yang tersembunyi."

Dari sini dapat dimengerti bahwa mengenai yang dimaksud dengan kata lain tersebut adalah takwil. ${ }^{14}$ Al Sakhrasi dalam kitab Madhhabushulal-Hanafiyyah juga memberikan pengertian kepada takwil yaitu:

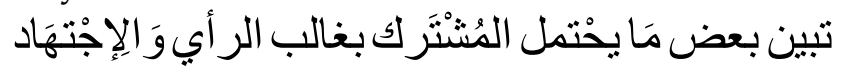

Artinya: “Takwil menjelaskan sebagian yang dikandung oleh lafadz musytarak dengan memiliki kemampuan dan penguasaan mengenai $\mathrm{ra}^{\prime} y u$ dan ijtihad."15

Dari berbagai definisi yang menerangkan bahwa takwil itu berbeda dengan tafsir dapat disimpulkan bahwa ulama mendefinisikan takwil sebagai metode Istinbath Ahkam dengan mengalihkan dari makna dhahir ke makna yang tersembunyi dengan dalil yang dapat dijangkau agar takwil tersebut dapat diterima.

Para ulama Ushul as Syafiiyah membedakan macam takwil menjadi tiga bentuk berdasarkan dekat dan jauhnya dalilnya. Bentuk yang pertama ialah takwil qarib. Takwil ini tidak beranjak jauh dari makna dhahirnya,sehingga dengan petunjuk yang sederhana bisa mudah dipahami. Contohnya dalam melakukan takwil di Q.S Alالعزم على أداء الصلاة yang ditakwil menjadi إذا قمتم إلى الصلاة Maidah ayat 6 yang berbunyi yang berarti keinginan atau kemauan untuk melaksanakan shalat. Maka saat berbicara hukum wudhu menjadi wajib dilakukan sebelum melakukan shalat karena menjadi syarat sahnya shalat. Sedangkan bentuk takwil yang kedua ialah takwil baid. Takwil ini yaitu pengalihan makna lafadz yang sangat jauh sehingga dalilnya tidak

${ }^{13} \mathrm{Al}$ Subki Abd. Al Wahhab bin Ali, Al Jawami' Fi Ushul Al Figh (Beirut: aL Kutub aL Ilmiah, 2003).54.

${ }^{14}$ Muhammad bin Abdullah Al Zarkasyi, Al Burhan Fi Ulum Al Quran (Kairo: Dar al Hadist, 2006).443.

15 Ahmad bin Abu Sahl As-Sarakhsi, Ushul As-Sarakhsi (Bairut: Dar al-Kutub al-Ilmiah, 1993).127.

DIKTUM: Jurnal Syariah dan Hukum Volume 19 Nomor 1 Juli 2021 
Kontribusi Konsep Takwil Ulama...

dapat diketahui dengan sederhana. Contohnya dalam zakat 40 ekor kambing zakatnya ialah 1 ekor kambing, dalam hal ini imam Hanafi berpendapat bahwa harta yang nilainya sama dengan 40 ekor kambing maka boleh dikeluarkan zakatnya sama dengan itu. Maka takwil seperti ini menurut syafii tergolong takwil baid. Takwil yang ketiga yakni takwil mutaadzar yang merupakan takwil tanpa adanya dalil yang menopang. Sehingga takwil ini dianggap terlarang ${ }^{16}$.

Dengan beberapa bentuk tersebut, mengenai diterimanya takwil oleh ulama dibagi menjadi takwil maqbul dan ghairu maqbul. Takwil maqbul merupakan takwil yang dapat diterima dan memenuhi persyaratan yang ditentukan para ulama ushul. Sedangkan yang ghairu maqbul merupakan yang tidak memenuhi syarat takwil sehingga tidak bisa diterima. Adapun ulama lain ada yang menggunakan istilah takwil sahih dan takwil fasid. Sehingga pada prinsipnya diterima atau tidaknya suatu takwil harus melihat keberadaam dalil yang menyertai pemindahan maknanya. Dalil yang kuat dan dapat dimengerti maksudnya dengan petunjuk yang sederhana maka bisa diterima. Sedangkan takwil yang dalilnya lemah atau bahkan tidak memiliki dalil maka dianggap takwil fasid. ${ }^{17}$

Takwil memiliki dua macam, yang pertama ialah takwil Al-Qur'an atau hadis yang diduga mengandung bentuk penyamaan sifat tuhan dengan apa yang berlaku dikalangan manusia, padahal diketahui bahwa tidak ada yang menyamai Allah swt. Contohnya ialah dalam Q.S Al-Fath ayat 10 yang berbunyi:

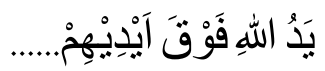

Terjemahnya: “Tangan Allah di atas tangan mereka...”18

Pada ayat ini Allah menyatakan secara lahiriyah atau dhahirnya bahwa tangan Allah berada di atas tangan mereka,maka saat memaknai dengan seperti itu maka bertentangan dengan kaidah Allah yang lain bahwa Allah itu tidak sama dengan makhluknya manusia. Selain itu juga mendefinisikan komponen dari tangan maka disana terdapat jari, kuku,kulit dan sebagainya, sedangkan ini tidak layak bagi Allah yang berbeda. Maka dilakukan takwil bahwa yang dimaksud ialah kekuasaan Allah sebagai makna yang paling dekat dan tidak bertentangan. Hal ini juga dapat

${ }^{16}$ Muhammad Ali Al Syaukani, Irsyad Al Fuhul Ila Tahqiq Al Haq Min Ilm Al Ushul (Riyad: Dar al Fadilah, 2000).

${ }_{17}$ Amir Syarifudin, Ushul Fiqih Jilid 2 (Jakarta: Kencana Prenada Media Groub, 2008).43.

${ }^{18} \mathrm{Al}-\mathrm{Qur}$ an,48:10.

DIKTUM: Jurnal Syariah dan Hukum Volume 19 Nomor 1 Juli 2021 
Kontribusi Konsep Takwil Ulama...

dijangkau dengan penjelasan bahwa dengan dengan kekuasaan atau tangan bisa mengatur bawahannya. ${ }^{19}$

Macam yang kedua yakni takwil bagi nas yang khusus berlaku hukum taklifi yang berusaha mengkompromikan antar hukum dalam ayat Al-Qur'an atau hadis yang secara dhahirnya terlihat bertentangan. Takwil ini disebabkan ada dua dalil yang yang bertentangan dan tidak bisa dikompromikan. Hal ini dilakukan berdasarkan kaidah mengamalkan dua dalil yang bertentangan lebih baik daripada membuang keduanya atau salah satu di antaranya. Contohnya ialah takwil yang dilakukan pada Q.S Al-Baqarah ayat 240 yang bertentangan dengan ayat 234 .

Ranah yang dimasuki metode takwil berdasarkan pengertiannya merupakan lafadz - lafadz yang tergolong lafadz nash dan dhahir. Yaitu yang masih memungkinkan adanya takwil. Adapun lafadz yang tidak menerima dan membuka takwil ialah yang sudah qathi, mufassar dan muhkam yang semua ini sudah memiliki satu makna yang jelas menurut syariah. ${ }^{20}$ Namun perlu ditegaskan dalam takwil mengalihkan makna tidak meninggalkan makna dhahir lafadz. Selain itu dilakukan juga pada ayat yang bersifat mujmal yang belum diperjelas (tafsir). Dalam hal ini seperti ayat yang menerangkan mengenai mengusap kepala yang dilakukan saat berwudhu disana masih mujmal mengenai kadarnya walaupun jelas lafadznya. Maka dalam ayat ini masih membuka takwil yang sekedarnya.

Ada beberapa syarat yang perlu diperhatikan saat menggunakan metode takwil yaitu ${ }^{21}$ :

a. Ada penyebab terjadinya takwil seperti adanya pertentangan antara dua dalil dan akan sulit dijalankan jika tidak ditakwilkan. Maka disini menghendaki untuk adanya takwil.

b. Karena takwil merupakan metode ijtihad untuk nash yang dzanni maka takwil tidak boleh dilakukan dengan menggugurkan nash syari yang lainnya atau nash yang bersifat qathi.

c. Takwil dilakukan pada lafadz yang menerima untuk di takwilkan. Beberapa lafadz itu diantaranya seperti lafadz yang masih umum, dan ditaqyid atau lafadz haqiqi yang diartikan secara majazi.

${ }^{19}$ Syarifudin, Ushul Fiqih Jilid 2.45.

${ }^{20}$ Abd al-Karim Zaidan, Al-Wajiz Fi Ushul Al-Figh (Baghdad: Muassasah Qurtubah, 1976).341.

${ }^{21}$ Dedi, "Konsep Ta'wil Ushuliyyin Dan Relevansinya Dengan Pembaharuan Hukum Islam."

DIKTUM: Jurnal Syariah dan Hukum

Volume 19 Nomor 1

Juli 2021 
Kontribusi Konsep Takwil Ulama...

d. Takwil dilakukan pada nash dengan petunjuk dalil yang shahih dan makasud lainnya yang digunakan harus lebih kuat atau rajih daripada makna dhahirnya. ${ }^{22}$

e. Takwil dalam pengalihan maknanya tidak boleh bertentangan dan harus selaras dengan bahasa Arab, makna Urf maupun makna syar'inya. ${ }^{23}$

f. Para mujtahid yang melakukan takwil harus merupakan seseorang yang memiliki kemampuan bahasa Arab dan juga ilmu syar'i.

Jadi pada intinya walaupun takwil ini menyimpang dari pemahaman dhahir ayat Al-Qur' an maupun hadis namun hal ini dalam waktu tertentu bisa dibenarkan jika memenuhi syarat yang telah ditentukan. Takwil terkadang juga tidak dibenarkan juga dianggap salah jika tidak ada hal mendorong untuk dilakukan takwil, atau ada dorongan untuk melakukan takwil namun menyalahi ketentuan sehingga menyalahi hakikat, syarat dan menyalahi nash yang qathi. Maka pada hakikatnya semua ayat maupun wahyu berguna bagi manusia,dan saat ada yang yang bertentangan maka ulama berusaha memberikan solusinya yang salah satunya dengan metode takwil.

\section{Kewarisan Beda Agama}

Secara epistemologi kata mawarist merupakan bentuk jamak yang tunggalnya yaitu mīrāts dengan arti warisan. Dalam Al-Qur'an ada beberapa pemakaian istilah kata kerja waratsa seperti dalam Q.S Al-Naml ayat 16 "wa waritsa Sulaimān Dāwūd" artinya "Dan Sulaiman mewarisi Daud", yang maksudnya Nabi Sulaiman menggantikan kenabian yang terdahulu sebelumnya juga kerajaan Nabi Daud AS dan mendapatkan warisan dari ilmu pengetahuannya. Di Q.S Al-Zumar pada ayat 74 "wa auratsana al-ardha" yang berarti “....dan telah memberi kepada kami tempat ini". Juga dalam Q.S Maryam ayat 6 "yaritsuni wa yaritsu min āli $Y a^{\prime} q \bar{u} b$ " maknanya “...yang akan mewarisi aku dan mewarisi sebagian keluarga Ya'qub". Mawarist disebut juga dengan istilah farāidh yang merupakan jamak yang berasal dari kata farāidah. Lafadz ini berasal dari kata faradha yang memiliki arti ketentuan atau menentukan.

Lafadz farāidh maupun farìdhah memiliki arti sekumpulan tentang ketentuan mengenai seseorang yang berhak menjadi seorang ahli waris dan memiliki hak untuk mendapatkan warisan serta ahli waris yang tidak memiliki hak mendapatkan atau Mahjub, dan jumlah ukuran bagian yang didapatkan ahli waris. Dari ilustrasi ini dapat

22 Al Syaukani, Irsyad Al Fuhul Ila Tahqiq Al Haq Min Ilm Al Ushul.759.

${ }^{23}$ Al Syaukani.759.

DIKTUM: Jurnal Syariah dan Hukum Volume 19 Nomor 1 Juli 2021 
dimengerti bahwasannya fiqh mawarits ialah ilmu fiqh yang didalamnya mempelajari mengenai siapa saja ahli waris yang memiliki hak mendapatkan warisan, yang tidak memiliki hak menerima, juga jumlah pada bagian yang tertentu untuk diterima, serta bagaimana tata cara menghitungnya. Menurut pendapat Al-Syarbini yang dicantumkan dalam kitab Mughnī al-Muhtāj juz 3 berkata bahwasannya fiqih mawaris mempunyai keterikatan hubungan dengan pembagian harta warisan serta perhitungan untuk mengetahui jumlah bagian yang diterima oleh ahli waris dari harta warisan. ${ }^{24}$

Perbedaan agama yang menjadi penghalang untuk seseorang saling mewarisi ialah jika antar seorang ahli waris dengan al Muwarist, salah satunya menganut Islam dan non-muslim atau kafir. Contohnya, saat ahli waris beragama Islam dan yang meninggalkan harta warisan beragama Kristen ataupun sebaliknya. Dalam kitab Bidayah al Mujtahid Ibnu Rusydi menjabarkan mengenai kewarisan beda agama dengan terperinci dan jelas. Dia melakukan pembedaan mengenai pewaris serta ahli waris beragama Islam atau non-muslim juga mengenai pembagian kepada pewaris serta ahli waris yang beragama Islam atau yang telah murtad. ${ }^{25}$ Maka mengenai kewarisan beda agama dalam Islam terdapat perbedaan jika dalam pewarisan itu orang islam yang mendapatkan harta warisan.

Maka saat dikaitkan dengan istilah beda agama maka yang dimaksud dalam hal ini ialah jika dalam satu kewarisan ada pihak yang beragama Islam dan juga nonmuslim. Maka yang terfokus dalam penelitian ini mencangkup seorang ahli waris yang mewarisi harta dari seorang non-muslim baik dari orang tuanya, anaknya maupun yang masih memiliki hubungan kekerabatan dengan muslim tersebut. Hal ini dilakukan peneliti karena yang menjadi perbedaan para ulama ialah mengenai kewarisan ini.

Ada dua golongan besar yang mana salah satu pihak mengharamkannya dan pihak yang lainnya membolehkan kewarisan beda agama ini. Ulama yang mengharamkan kewarisan beda agama baik itu ahli warisnya non-muslim atau seorang muslim semuanya tetap haram. Pendapat ini dikukuhkan oleh imam Syafii, Hanafi, Maliki dan Hanbali. ${ }^{26}$ Semuanya bersepakat berdasarkan teks hadis yang

${ }^{24}$ Muhammad al-Syarbini Al-Khathib, "Mughī Al-Muhtāj" (Kairo: Musthafa al-Baby al-Halaby, 1958).3.

${ }^{25}$ Ibnu Rusyd Al-Qurthuby, Bidayatul Mujtahid Wa Nihayah Al-Muqtashid (Jakarta: Pustaka Aman, 1989).414.

${ }^{26}$ Muhammad Jawwad Mughniyah, Al-Fiqh Alā Madzhab Al Khamsah (Kairo: Maktabah al Fikrah, 1993).

DIKTUM: Jurnal Syariah dan Hukum Volume 19 Nomor 1 Juli 2021 
Kontribusi Konsep Takwil Ulama...

melakukan pelarangan bahwa orang yang beragama Islam tidak bisa mewarisi orang yang kafir atau orang kafir tidak mampu mewarisi seorang muslim berdasarkan dalil hadis berikut:

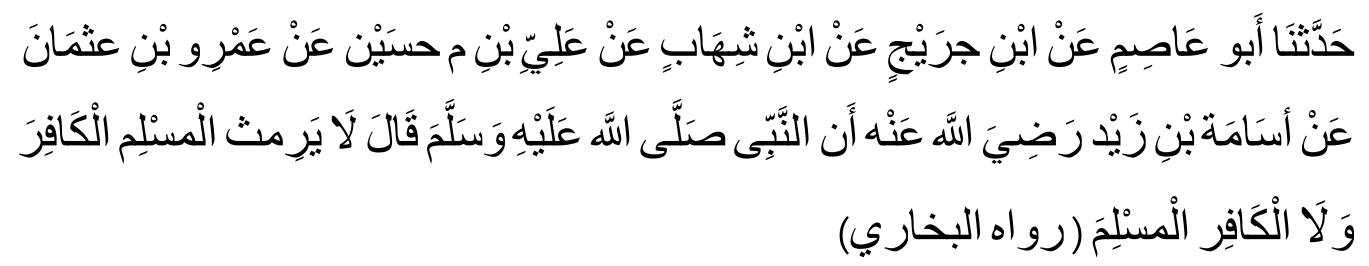

Artinya: Telah menceritakan kepada kami dari Abi Ashim dari Ibnu Juraij dari Ibnu Syihab dari Ali bin Husain dari Amr bin Usman dari Usamah bin Zaid dari Nabi saw bersabda: "Orang muslim tidak mendapat warisan dari orang kafir, dan orang kafir tidak mendapat warisan dari orang muslim."(H.R Bukhari) ${ }^{27}$

Berdasarkan hadis ini imam Syafii dengan tegas menolak pemaknaan bahwa yang dimaksud dalam hadis ini ialah kafir harby saja. Menurutny, tidak ada perbedaan antara kafir harby maupun dzimmi karena keduanya sama-sama kafir. Selain itu, tidak ada nas yang menunjukkan bahwa ada takhsis pada dalil ini.

Selanjutnya yaitu golongan yang membolehkan yaitu golongan dari Ibnu Taimiyah, Ibnu Qayyum al Jauziyah. Diceritakan pada kitab Ahkamu Ahli Zimmah, bahwa Imam Ibnu Taimiyah telah berkata bahwa telah dicantumkan dalam hadis yang mutawatir mengenai sikap nabi dalam memperlakukan orang-orang zindiq dan juga munafik untuk masalah dhahiriyah tidak membedakan dengan hukum yang diberlakukan bagi muslim dan mereka juga saling mewarisi. Ketika ada seseorang yang bernama Abdullah bin Ubay atau yang lainnya berbohong untuk mengelabuhi bahwa beriman kepada Al-Qur'an, Rasulullah tidak membolehkan untuk jenazah tersebut dishalatkan dan memintakan ampun atas dosa-dosanya, namun mereka dapat diterima warisannya oleh orang muslim yang menjadi ahli warisnya yaitu Abdullah bin Ubay. Kemudian Rasulullah juga tidak mengambil Sebagian banyak atau kecil dari harta peninggalan tersebut dan tetap menyerahkan kepada ahli waris

${ }^{27}$ Muhammad bin Ismail Abu Abdullah al Bukhary, Sahih Bukhari (Beirut: Darul Ibnu Katsir, 1987).18.

DIKTUM: Jurnal Syariah dan Hukum Volume 19 Nomor 1 Juli 2021 
Kontribusi Konsep Takwil Ulama...

yang berhak. Dari pertanyaan ini bisa diketahui bahwa mengenai harta warisan itu berdasarkan kepada kepada الظاهرةالنصر bukan bukan ikatan batin atau المولاة الباطنت

Sedangkan menurut pendapat Mu'adz atau Muawiyah mengenai kebolehannya seorang yang beragama Islam menerima harta warisan dari orang yang kafir, mereka mengartikan lafadz كفر pada hadis "orang muslim tidak boleh mewarisi orang kafir dan orang kafir tidak boleh mewarisi orang muslim" hanya berlaku untuk seorang kafir harby dan tidak berlaku untuk kafir zimmi. Kedua ulama tersebut berpendapat, walaupun kata "kafir" disini berlaku amm tetapi dalam hadis ini hanya ditakhsis terhadap kafir harbi.

\section{Kontribusi Takwil dalam Kewarisan Beda Agama}

Berdasarkan pendapat dari dua golongan yang memberikan hukum mengenai kewarisan antara muslim dengan nonmuslim maka yang diketahui memberikan kelonggaran dan memperbolehkan dalam melakukan ini ialah berasal dari golongan Ibnu Taimiyah dan muridnya Ibnu Qayyum al Jauziyah. Selain itu, pendapat ini merupakan yang diikuti oleh ulama kontemporer seperti Yusuf Qardhawi mengenai bolehnya kewarisan beda agama. ${ }^{29}$

Hal ini diungkapkan oleh Yusuf Qardhawi dengan berdalil bahwa perlu adanya reinterpretasi ulang pada hadis yang digunakan sebagai dalil secara mutlak larangan saling mewarisi antara seorang muslim dan non-muslim. Penjelasan mengenai pernyataan ini dipaparkan dalam kitab fi Figh al-Aqalliyat al-Muslimah bahwa perlu ada kemaslahatan yang dijadikan tujuan akhir dalam menentukan hukum ini.

Dalam pendapatnya, Yusuf Qardhawi lebih memilih untuk mendukung argumen yang tidak menjadi mayoritas dari ulama, namun mengambil dari pendapat minoritas yang membolehkan adanya kewarisan beda agama. Al Qardhawi mendasarkan pendapatnya pada beberapa riwayat yang berasal dari ‘Umar, Muadz, Muawiyah yang memberikan kebolehan bagi orang Islam mendapatkan harta warisan dari seorang non-muslim. Hal ini dikaitkan dengan kesamaan bolehnya

${ }^{28}$ Ibn Qayyim al Jauziyah, Ahkamu Ahl Zimmah (Beirut: Dar al Hadist, 1995).854.

29 Baihaqi, "Revitalisasi Maqasid Al-Shariah: Pembacaan Ulang Konsep Kewarisan Beda Agama."

DIKTUM: Jurnal Syariah dan Hukum Volume 19 Nomor 1 Juli 2021 
Kontribusi Konsep Takwil Ulama...

seorang laki-laki muslim menikah dengan perempuan ahli kitab serta larangan lelaki ahli kitab menikahi seorang wanita yang muslim. ${ }^{30}$

Yusuf Qardhawi juga memaparkan bahwasannya hadis ini larangan mewarisi antara orang kafir dengan muslim tidak bisa diartikan secara mutlak dan tekstual. Menurut Yusuf Qardhawi hadis ini masih memiliki makna yang lebih luas. Kata kafir disini masih bisa ditakwilkan seperti dalam pandangan imam Hanafi berdasarka teori penafsiran hadis secara muqayyad. Takwil di sini lebih mengkhususkan lafadz kafir terhadap kafir harby saja, sehingga harta warisan akan tetap bisa diberikan selama muwarisnya bukan seorang kafir harby. ${ }^{31}$

Dari pernyataan ini dapat diketahui bahwa dalam hal ini Yusuf Qardhawi tidak menggunakan makna dhahir dari kafir yang secara keseluruhan dan memilih membatasi dengan tetap adanya kebolehan seorang muslim menjadi ahli waris dari non-muslim. Maka metode ini digolongkan sebagai metode takwil yang mana dia mengkhususkan makna pada kafir harby dan tidak pada ahlu dzimmi. Pada hadis itu kata kafir tidak mutlak pada seluruh orang kafir, namun hanya kafir harby saja. Para ulama juga menganggap bahwa orang muslim telah menolong ahlu dzimmi dengan tetap memberikan perlindungan bagi keluarganya dan berperang untuk mereka. Maka seorang muslim berhak atas harta warisan darinya dengan landasan tolong menolong yang telah dilakukan.

Pendapat ini juga diperkuat dengan dalil yang diterangkan pada Al-Qur'an Q.S Al-Nisa' ayat 140 Allah SWT berfirman:

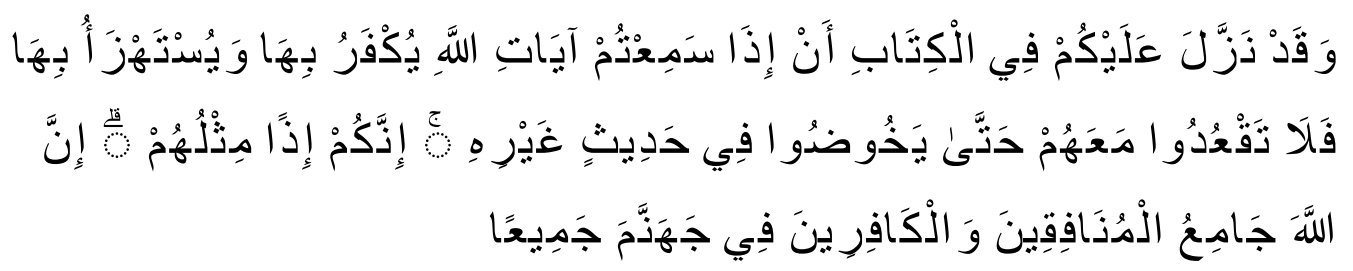

Terjemahnya: “Dan sungguh Allah telah menurunkan kekuatan kepada kamu di dalam Al-Quran bahwa apabila kamu mendengar ayat-ayat Allah diingkari dan diperolok-olokkan (oleh orang-orang kafir), maka janganlah kamu duduk beserta mereka, sehingga mereka memasuki pembicaraan yang lain. Karena sesungguhnya (kalau kamu berbuat demikian), tentulah kamu serupa dengan

${ }^{30}$ Yusuf Qardhawi, Fatwa-Fatwa Kontemporer, Jilid 3 (Jakarta: Pustaka Al-Kautsar, 2002).854.

${ }^{31}$ Qardhawi.

DIKTUM: Jurnal Syariah dan Hukum Volume 19 Nomor 1 Juli 2021 
mereka. Sesungguhnya Allah akan mengumpulkan semua orang-orang munafik dan orang-orang kafir di dalam Jahannam." ${ }^{32}$

Kata منافق yang terdapat pada ayat ini dikaitkan penyebutan secara terpisah dengan كemisahan ini tidak bertentangan dengan apa yang dinyatakan oleh ulama bahwa jika ada seorang kafir yang baru saja memeluk Islam, maka dia tidak perlu mengqadha' shalat yang telah ditinggalkannya sebelumnya. Namun jika ada seorang yang telah murtad dari agama Islam, lalu Ia kembali memeluk ajaran Islam maka dia harus mengganti seluruh shalat yang pernah ditinggalkannya saat menjadi kafir. ${ }^{33}$ Alasan lain adalah hadis di bawah ini.

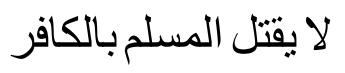

Artinya: "Seorang muslim, tidak boleh dibunuh (diqishas) karena membunuh orang kafir." (H.R. Bukhari)

Kata كافر yang dipahami dalam hadis ini ialah menyangkut kafir harby saja. Adapun kafir dzimmi tidak diperkenankan untuk dibunuh karena disamakan dengan seorang muslim. Hak untuk tetap mendapatkan warisan dari kafir dzimmi oleh umat Islam juga menjadi daya tarik bagi mereka,karena banyak dari kafir dzimmi yang khawatir saat memeluk agama Islam tidak bisa saling mewarisi dengan kerabatnya yang masih kafir. Kejadian ini banyak ditemui pada kalangan kafir dzimmi namun mereka tidak paham bahwa bisa tetap mendapatkan harta warisan saat sudah beragama Islam. Kemaslahatan seperti lebih mendatangkan banyak manfaat jika dibandingkan dengan syariat lainnya seperti tidak adanya larangan menikah dengan para ahli kitab dan pemahaman ini sesuai dengan kaedah ushul yang ada.

Ibnu Taimiyah juga berpendapat bahwa illat yang dimaksud pada permasalahan waris berdasarkan terhadap pertolongan serta kasih sayang. Sedangkan alasan yang menjadi penghalang adalah permusuhan. Secara dhahir orang muslim telah melindungi dan menolong kafir dzimmi dari serangan yang dilakukan oleh kafir harby serta membebaskan dari status tawanannya. ${ }^{34}$ Maka dari

${ }^{32}$ Al-Quran,4:140.

${ }^{33}$ Jauziyah, Ahkamu Ahl Zimmah.855.

${ }_{34}$ Tohari, "Rekonstruksi Hukum Kewarisan Beda Agama Ditinjau Dari Al-Ushul Al Khamsah."

DIKTUM: Jurnal Syariah dan Hukum Volume 19 Nomor 1 Juli 2021 
Kontribusi Konsep Takwil Ulama...

itu orang Islam berhak mewarisi harta dari kafir dzimmi. Tetapi menurutnya kafir dzimmi tidak boleh menerima warisan dari orang yang beragama Islam karena dalam bathinnya, kafir dzimmi memiliki kesamaan dengan kafir harby akidahnya memusuhi agama Allah dan tidak mau percaya dengan kebenaran Allah.

Maka berdasarkan penjabaran ini kebutuhan untuk melakukan takwil pada hadis sehingga mendapatkan makna yang dimaksud berdasarkan dalil yang dapat dijangkau telah terpenuhi. Jika tetap dimaknai bahwa kafir yang dimaksud dalam hadis itu ialah seluruh non-muslim tanpa memperhatikan dari golongan kafir harby maupun ahlu dzimmi maka hal ini akan membawa kemudharatan yang lebih besar bagi umat Islam.

\section{Kesimpulan}

Takwil menurut ulama Ushuliyyun merupakan pemindahan makna dari dhahir kepada makna tersembunyi karena adanya dalil yang menunjukkan bahwa itu lebih tepat dan sesuai dengan yang dimaksud. Adapun relevansinya dengan perkembangan hukum Islam khususnya pada produk hukum mengenai kewarisan beda agama dapat diketahui bahwa saat dalil itu ditakwilkan akan menghasilkan hukum yang lebih mampu mengatasi permasalahan masyarakat dan relevan dengan membatasinya pada kafir harby saja untuk tidak saling mewarisi. Sehingga dapat diketahui bahwa berdasarkan takwil yang dilakukan oleh para ulama seperti Ibnu Taimiyah, Ibnu Qayyum al Jauziyah dan ulama kontemporer Yusuf Qardhawi seorang muslim tetap bisa mendapatkan harta warisan dari seorang non-muslim dengan berlandaskan tolong menolong yang telah dilakukan kaum muslim. Namun hal ini tidak berlaku sebaliknya karena ahlu dzimmi tidak menolong muslim dengan kekafirannya.

\section{Daftar Pustaka}

Al-Qur'Ān Al-Karīm, n.d.

Abd. Al Wahhab bin Ali, Al Subki. Al Jawami' Fi Ushul Al Fiqh. Beirut: aL Kutub aL Ilmiah, 2003.

Al-Khathib, Muhammad al-Syarbini. "Mughī Al-Muhtāj." Kairo: Musthafa al-Baby alHalaby, 1958.

Al-Qurthuby, Ibnu Rusyd. Bidayatul Mujtahid Wa Nihayah Al-Muqtashid. Jakarta: Pustaka Aman, 1989.

Ali, Abi Bakr Bin. Bayan Al-Mukhtashar Syarh Mukhtashar Al-Muntaha Al-Ibn Al-Hajib Fi Ushul Al- Fiqh. Jami'iyah Um al Quro', n.d.

DIKTUM: Jurnal Syariah dan Hukum

Volume 19 Nomor 1

Juli 2021 
Siti Zuhrotun Ni' mah \& Tutik Hamdani:

Kontribusi Konsep Takwil Ulama...

As-Sarakhsi, Ahmad bin Abu Sahl. Ushul As-Sarakhsi. Bairut: Dar al-Kutub al-Ilmiah, 1993.

Effendi, Satria. Ushul Fiqih. Jakarta: Kencana, 2009.

Hafzah, Abu. Ensiklopedi Fiqih Al. Ponorogo: Pustaka al-Bayyinah, 2014.

Ismail Abu Abdullah al Bukhary, Muhammad bin. Sahih Bukhari. Beirut: Darul Ibnu Katsir, 1987.

Jauziyah, Ibn Qayyim al. Ahkamu Ahl Zimmah. Beirut: Dar al Hadist, 1995.

Mughniyah, Muhammad Jawwad. Al-Figh Alā Madzhab Al Khamsah. Kairo: Maktabah al Fikrah, 1993.

Qardhawi, Yusuf. Fatwa-Fatwa Kontemporer, Jilid 3. Jakarta: Pustaka Al-Kautsar, 2002.

Syarifudin, Amir. Ushul Fiqih Jilid 2. Jakarta: Kencana Prenada Media Groub, 2008.

Syaukani, Muhammad Ali Al. Irsyad Al Fuhul Ila Tahqiq Al Haq Min Ilm Al Ushul. Riyad: Dar al Fadilah, 2000.

Wahbah az-Zuhaili. Ushul Al-Figh Al-Islami. Damsyiq: Dar al-Fikr, 1986.

Zaidan, Abd al-Karim. Al-Wajiz Fi Ushul Al-Fiqh. Baghdad: Muassasah Qurtubah, 1976.

Zarkasyi, Muhammad bin Abdullah Al. Al Burhan Fi Ulum Al Quran. Kairo: Dar al Hadist, 2006.

\section{Artikel Jurnal}

Baihaqi, Wahid Ahtar. "Revitalisasi Maqasid Al-Shariah : Pembacaan Ulang Konsep Kewarisan Beda Agama." Muslim Heritage 1, no. 2 (2017): 107-24.

Dedi, Syahrizal. “Konsep Ta'wil Ushuliyyin Dan Relevansinya Dengan Pembaharuan Hukum Islam." Jurnal Ilmiah Syariah 17, no. 01 (2018): 1-18.

Dedi, Syarial. “Ushul Al-Fiqh Dan Kontribusinya (Konsep Ta'wil Dan Relevansinya Dengan Pembaharuan Hukum Islam)." Al Istinbath: Jurnal Hukum Islam 2, no. 2 (2017): 103-6.

Tohari, Chamim. "Rekonstruksi Hukum Kewarisan Beda Agama Ditinjau Dari AlUshul Al -Khamsah." Mazahib : Jurnal Pemikiran Hukum Islam 16, no. 1 (2017): 14. https://doi.org/: http://dx.doi.org/10.21093/mj.v16i1.625.

Zainuddin, moh ridwan. “Tafsir,Ta'wil Dan Terjemah.” Al-Allam 1, no. 1 (2020): 1-17.

DIKTUM: Jurnal Syariah dan Hukum Volume 19 Nomor 1 Juli 2021 